\title{
Organization and Provision of Buses Operation on the Route Taking Into Account the Expenditures of Participants of the Transportation Process
}

\author{
M. M. Moroz ${ }^{1}$, V. L. Khorolskyi ${ }^{1}$, O. V. Moroz ${ }^{1}$ K. V. Vasylkovska ${ }^{2}$, V. V. Herasymchuk ${ }^{1}$ \\ ${ }^{1}$ Kremenchuk Mykhailo Ostohradskyi National University, \\ ${ }^{2}$ Central Ukrainian National Technical University, \\ *Corresponding authorE-mail: mykolai.moroz@gmail.com
}

\begin{abstract}
The purpose of research. Determination of the optimal number of buses, taking into account the opposite economic factors and economic feasibility in new routes of passenger transport when changing the parameters of transport system using legislative methods and norms. Methods: The article defines the total expenditures of participants of passenger transportation process, which is influenced greatly by the number of buses on the route: on one hand, a large number of them provides the least amount of waiting time, on the other hand, with such quantity of buses carrier's expenditures increase, as well as the estimate and the cost account of the bus operation on the route using regulatory documents.

Results: Using of the proposed methodology allows organizers and performers, in accordance with the current legislation, to overestimate (underestimate) costs deliberately (unintentionally), determine the economic expediency of opening new routes and calculating fares on existing routes and optimal number of buses on the route taking into account the influence of opposite factors. The compromise of the interests of the carrier and the passenger is influenced by the transport service time cost, operating costs and turnover time. Daily operating costs of the route studied and the volume of passenger traffic flow indicate that at the socially preferential (specified) by local council fare the carrier can cover expenditures by increasing the fare or targeted subsidies (subventions).
\end{abstract}

Keywords: cost estimates, cost of passenger time, cost value, number of vehicles, operational costs, operating costs of the carrier.

\section{Introduction}

Conditions of human life are connected with physiological cyclicality and sociological peculiarities which in turn cause significant fluctuations of passenger traffic flow in time and in the direction of the transport network. The accounting of the dynamics of the passenger traffic flow formation is one of the most demanding tasks in conducting transport calculations, which should be aimed at minimizing fluctuations in the section of the network due to a series of organizational measures [1 - 3]. One of the main tasks of optimizing the transport system and the rational organization of urban bus transportation is the definition of the need for new routes and the economic provision of transport vehicles. Nowadays, the issue of the rolling stock structure is acute in terms of their number, passenger capacity, categories and fuel consumption, and environmental indicators.

The solution of this task is to study the mobility of passenger traffic flow between different residential neighbourhoods of the city and the choice of route schemes that will meet the needs of the direct transportation.

The most accurate calculations are obtained when passenger transportation is forecast by the method of calculation of transport area mutual correspondence, which is based on the calculation of population mobility [1]. The idea of this method is that the entire structure of the settlement with a large number of passenger forming and absorbing correspondence is presented in an enlarged form (transport areas). This method requires the account of each social group.

The choice of the rolling stock capacity, determined by its modifications [ $4-6]$, is determined by the following factors: the nature of the passenger traffic flow, the appropriate frequency of vehicles in a certain period, the road conditions of the movement, economic provision of operation on the route.

The rational organization of urban passenger transportation on the basis of the choice of optimal structure of rolling stock in the passenger transportation affects the level of costs and the formation of transportation cost value, and hence the determination of the efficiency of the bus operation on the route, since passenger transportation cost value is considered as an indicator of economic efficiency $[7,8]$.

As a criterion for transportation effectiveness, in research [3], specific costs for the delivery of goods from departure point to destination point are offered, but such a method for determining passenger transportation cost value is considerably complicated, taking into account the unevenness of passenger traffic flow.

Determining economic expediency in new routes of urban passenger transportation by changing the parameters of transport system is possible through the use of legal methods and norms [9]. Carriers are faced with the task of choosing measures that are most effective and require lower costs. It is noted that the quality indicators are determined as dependence on the parameters that describe the conditions of movement $[1,8]$. Also, the efficiency of passenger transport operation is determined by the form of qualita- 
tive and quantitative expression of the purpose of public transport services $[7,10]$.

Vehicles (V) operation on the route affects the total amount of time spent by the population on commute and its effective use [3, $11,13]$. Some of the criteria are reducing the time spent by passengers on trips, the efficiency of buses operation and carrier's income rate $[9,10]$. According to $[4,5,12]$, the quality of product or service is a set of its properties, which determine the ability to meet the needs of the population.

\section{Related Work}

In this paper, it is proposed to consider a criterion based on the concept of social and ethical demand for bus transportation. Its organization (in the context of market relations) makes provision for the reduction of social and economic costs to meet existing demand. As far as passengers and carriers are concerned, a generalized criterion for assessing the total costs of participants in the transportation process $\sum Z$ is proposed, which tends to minimize as a result of organization of transportation:

$\sum Z=Z_{p e r}+Z_{p a s} \rightarrow \min$

where $Z_{p e r}$ is carrier's operating costs;

$Z_{p a s}$ is cost estimation of social expenses of commuting time.

Operating costs of an enterprise are defined as a product of daily operating costs of one vehicle $Z_{e k}$ and the number $n$ of vehicles operating on a certain route:

$Z_{p e r}=Z_{e k} n$.

Social costs include waiting time for vehicle $t_{o g}$, which is determined by the formula:

$t_{o g}=\frac{I}{2}=\frac{T_{o b}}{2 n}$

where $I, T_{o b}$ are interval of vehicle movement and route time duration, $h$.

Then social costs are determined by the formula:

$Z_{\text {pas }}=\frac{V_{p a s-h} T_{o b}}{2 n}$,

where $V_{p a s-h}$ is a generalized criterion for segmentation of the passenger hour cost, which is calculated as a fraction of the division of passenger income into the working time fund:

$V_{p a s-h}=\frac{D_{m}}{F_{m h}}$,

where $D_{m}$ is passenger monthly income, $\mathrm{UAH}$;

$F_{m h}$ is monthly working time fund, h.

This criterion defines the purchasing power of town dwellers and indirectly characterizes its inquiries regarding the quality of transportation, which are characterized by the cost of commuting time and the level of comfort. Last but not least is the fact that the cost of one passenger-hour represents the measurement of time and cost of passenger transportation.

Substituting (2) and (4) into (1), we obtain:

$$
\sum Z=Z_{e k} n+\frac{V_{p a s-h} T_{o b}}{2 n} .
$$

When determining the operating costs, attention is drawn to the articles [14]. Various parameters can be chosen as an argument for calculating hourly expenses. In our case, the argument is the number of vehicles on the line, which depends on the interval of the rolling stock movement and the time spent waiting by passengers at the stop. The argument may also be the cost of high-speed transport purchasing, which determines the passenger's time.

To estimate the expression (6) quantitatively and to determine the nature of the impact of vehicles amount on the carrier and passenger costs, and total costs, it is possible to develop diagrams for these components for any settlement using the standard methodology for the formation of transport services cost value [14]. The optimal value of vehicle number will determine the minimum value of the saddle curve of total costs.

To verify the theoretical dependencies of costs and determine the optimal value of vehicle number on the route empirically, we build diagram of operating costs and waiting time expenditures on the example of the existing bus route No. 1 in the town of Kremenchuk.

The results of route cost value calculation are put into Table 1 .

Table 1: Estimated operation cost on the route per month for the route number 1 in the town of Kremenchuk

\begin{tabular}{|l|l|l|}
\hline 1 & \multicolumn{1}{|c|}{ Variable costs } & UAH \\
\hline 1.1 & Labor remuneration fund of production & 12972,86 \\
\hline 1.2 & Deductions for social events & 4784,392 \\
\hline 1.3 & Total ind. entrepreneur with deductions & 17757,25 \\
\hline 1.4 & Costs of fuel and lubricants & 104620,1 \\
\hline 1.5 & Costs of maintenance and repair & 7938,588 \\
\hline 1.6 & Costs of repair and tires change & 787304,9 \\
\hline 1.7 & Total variable costs & 917620,8 \\
\hline 2 & Fixed costs & \\
\hline 2.1 & Depreciation deductions & 2540,567 \\
\hline 2.2 & General economic costs & 138024,2 \\
\hline 2.3 & Total fixed costs & 140564,8 \\
\hline \multicolumn{2}{|c|}{ Total costs } & 1058186 \\
\hline
\end{tabular}

According to the costs, we build a compromise diagram for the bus route number 1 in Kremenchug, which reflects the nature of the principal search scheme for any route, and is depicted in Fig. 1 The saddle curve is constructed for different routes, taking into account changes in the cost of the passenger-hour and the costs of the transport company for transportation performance. The point of intersection of the curve shows the Pareto optimal area, leaving which the costs of the carrier or passenger will increase.

Theoretically, the optimum number of vehicles can be determined by differentiating equation (6) by the number of vehicles $n$, we obtain:

$\frac{d \sum Z}{d n}=Z_{e k}-\frac{V_{p a s-h} T_{o b}}{2 n^{2}}$

\section{$Z_{\text {pas }}$}

$Z_{\text {per }}$

$\sum Z$

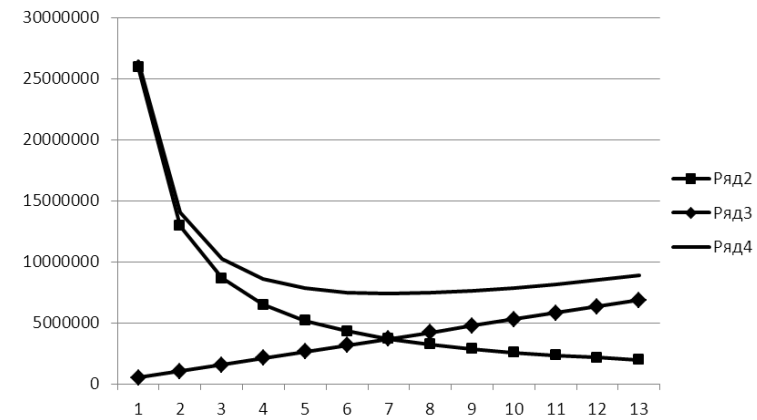

Fig. 1: Diagram for searching compromise between the expenditures of the passenger and the carrier for the route number 1 Kremenchuk. 
From the equation $\frac{d \sum Z}{d n}=0$ we find the optimal value of the number of vehicles:

$n_{o p t}=0,71 \sqrt{\frac{V_{p a s-h} T_{o b}}{Z_{e k}}}$.

Thus, the optimal value of number of vehicle is directly proportional $\sqrt{\frac{V_{p a s-h} T_{o b}}{Z_{e k}}}$. The higher their number on the route is, the less the waiting time for passengers is, which reduces social costs, but the greater the operating costs of the carrier are.

The combination of these aspects will balance the economic effect of the provision of transport services as well as the social aspect, which directly affects the development of a town as a whole.

The process of passenger transportation organization is based not only on the rolling stock increase, but also causes the need to solve a number of issues aimed at the development the material and technical base, monitoring technical conditions and operation time of vehicle in order to ensure a high level of transportation safety.

The carrier's expenses items are based on the norms of spending resources, approved by the Ministry of Infrastructure of Ukraine, considering that the reporting data of a particular subject may reflect its high or low level as mismanagement of the carrier and be deliberately (inadvertently) overestimated (understated).

The calculation of the economic provision of passenger transportation is carried out according to [15]. The current calculation of the fare level is determined by the calculation items, respectively [14], namely, driver salary, Single Social Contribution, fuel and lubricants, automobile tires, repairs and maintenance of vehicles, vehicle depreciation and overall production expenditures. It should be noted that the updated list of calculating items excludes the "Transport fee" item, which is currently taxed in the "Fuel" item. That is, this item is replaced from constant expenditures (when the fee was executed for a calendar period, years) to variable expenditures (depending on the volume of the work completed that is fuel consumption).

For an example, let's consider the "Center - Prikhodka Street" route in Kremenchuk, which is proposed to open by local selfgovernance as a social one with a minimum fare.

1. The length of the route in the forward and backward directions is $4,2 \mathrm{~km}$.

2. Zero mileage is $10 \mathrm{~km}$.

3. Number of runs per day is 22

4. Total mileage per day is $4.2 \times 22+10=102.4 \mathrm{~km}$

5 . Number of drivers on a vehicle is 2 people.

6. Number of vehicles on the route is 1 (RUTA - gas).

8. Average number of paid passengers transported per day is:

week day - 193 pass;

weekend - 138 pass.

Passenger traffic studies were carried out on 02/25/2018 (Sunday) and on $02 / 28 / 2018$ (Wednesday).

9. Working hours per day are 10 .

In order to study the public demand for transportation, a matrix method was used to survey passenger traffic flow and correspondence [13]. This method involves the use of a matrix for the study of passenger correspondence (Fig. 2), in which the recorder indicates the number of passengers entered at each stop and filled in matrixes on the route passenger correspondence at their departure stop, for each run. The matrix contains the route number, the time of vehicle departure, the name of stops.

State Vehicle Number

$$
\text { Run No. }
$$

\begin{tabular}{|c|c|c|c|}
\hline $\begin{array}{l}\text { Route №_ Direction 1 direct } \\
\text { Departure time: }\end{array}$ & $\begin{array}{c}\text { Route № _ Direction 1 direct } \\
\text { Departure time:-_ }\end{array}$ \\
\hline Stop name & Number of & Stop name & Number of \\
\hline
\end{tabular}

\begin{tabular}{|c|c|c|c|c|c|}
\hline & \multicolumn{2}{|c|}{ pass. } & \multirow[t]{2}{*}{ left } & \multicolumn{2}{|c|}{ pass. } \\
\hline & left & $\begin{array}{l}\text { en- } \\
\text { tered }\end{array}$ & & left & $\begin{array}{l}\text { en- } \\
\text { tered }\end{array}$ \\
\hline Centre & & & Railway st. & & \\
\hline Market & & & Lukas & & \\
\hline Post office & & & Aval Bank & & \\
\hline Aval Bank & & & Post office & & \\
\hline Lukas & & & Market & & \\
\hline Railway st. & & & Centre & & \\
\hline $\begin{array}{l}\text { Arrival time } \\
\text { Recorder's St }\end{array}$ & & & $\begin{array}{l}\text { Arrival time_ } \\
\text { Recorder's }\end{array}$ & & \\
\hline
\end{tabular}

Fig.2: Matrix of passenger correspondence research.

Application of matrix method, as a kind of table-calculation method of passenger traffic flow research, allows obtain highly reliable results and can be used, both in one-time and in continuous surveys. It is established in [10] that due to this method it is possible to identify the passenger traffic flow that is lost because of imperfection of bus operation organization and management on the route, which, in turn, leads to decrease in the volume of passengers and loss of carrier income.

As a result of the conducted studies, the data on passenger transportation by scheduled runs on a week day (Fig. 3) and at week end have been received (Fig. 4).

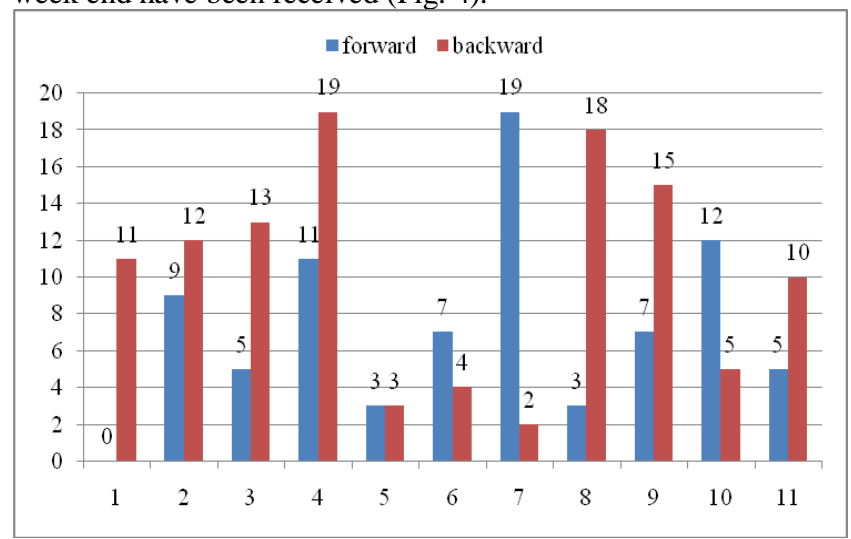

Fig. 3: Distribution of passenger traffic flow on route runs completed on a week day.

In accordance with the diagram of Fig. 3 it was established that the largest number of passengers was transported at the fourth run (30 people), the least number was 6 people. The average number of passengers on the vehicle was 17 .

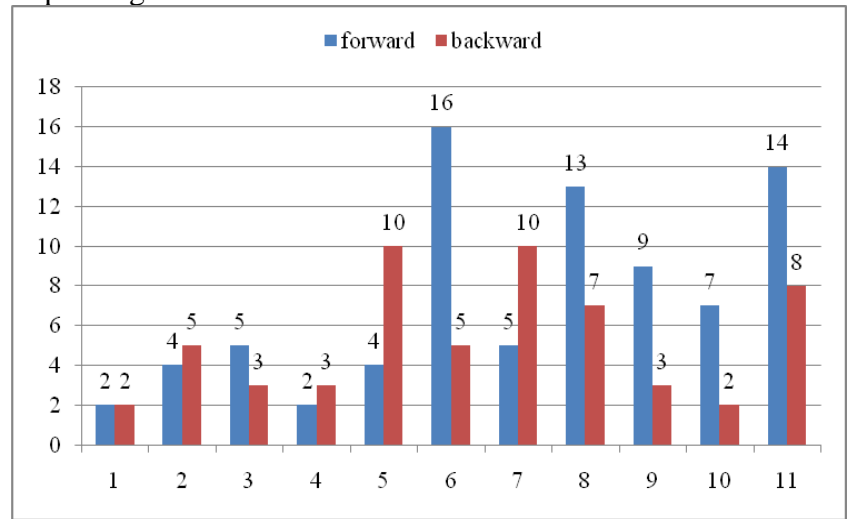

Fig. 4: Distribution of passenger traffic flow on route runs completed at week end.

According to the weekend results, we have the following: the largest number of passengers transported was at the fourth run (19 people), the least number was 4 people. The average number of passengers of the vehicle was 12 people.

Determination of performed transport work, namely the total number of passengers carried per day, is a decisive criterion for determining the cost of transportation, in accordance with $[14,15]$ and, accordingly, when establishing a transport fare.

In order to preserve the dependence between the bus class and fare 
rates, it is recommended to use the previously established hourly fare rates taking into account the calculated coefficients, which depend on the actual average wage of this category of employees. In accordance with [16] a fare rate of $120 \%$ of the minimum wage established by the legislation of Ukraine is stated. As of 01.01.2018, the minimum monthly wage size is set UAH 3723 .

Then, the average monthly wage is UAH 4467.6 (3723 x 1,2). With monthly working time fund of 176 hours ( 22 working days for 8 hours each), the hourly rate is UAH $4467.6 / 176=25.38$, the transition rate to tariff rates for small class bus drivers in cities with a population of up to 500 thousand will be $C_{\mathrm{r}}=25.38 * 1.729$ $=43.88 \mathrm{UAH}$. With the use of hourly wage system, the main driver's wages is WFD $=10 * 43.88=438.80 \mathrm{UAH}$

When planning drivers' wage fund (WF), you can take the value of additional pay as a percentage of its basic (for transport enterprises it is $15-20 \%$ ) or actual expenditures from previous periods and its correlation to the actual received basic wages.

Drivers' additional wage is:

$\mathrm{W}_{\mathrm{ad}}=438.80 * 0.15=65.82 \mathrm{UAH}$.

The total drivers' WF will be:

$\mathrm{WF}=438.80+65.82=504.62 \mathrm{UAH}$.

It should be noted that since January, 1, 2016, the size of the Single Social Contribution (SSC), which is regulated by [17, 18 ], is $22 \%$, which significantly reduces the tax pressure on the enterprise and, in turn, the cost of passenger transportation.

On the basis of the received personnel WF, the value of SSC is calculated and put into the estimate:

Vssc $=504.62 * 0.22=111.02 \mathrm{UAH}$.

Thus, WF along with SSC is:

$504.62+111.02=615.64$ UAH.

According to the "Fuel" and "Lubricants" items the following is planned: expenses for automobile fuel, lubricants and other exploitation materials in accordance with the applicable norms and prices (taking into account expenses for delivery to the place of preservation and distribution). Calculation of the need for automotive fuel is based on the total mileage taking into account current fuel consumption standards [19].

The linear (basic) rate of gasoline consumption for the Ruta bus is $10.51 / 100 \mathrm{~km}$ according to the current standards. The total corrective factor (taking into account the work in a city with a population of up to 0.5 million people $\mathrm{K} 1=5 \%$; with frequent stops associated with passenger loading and unloading $\mathrm{K} 2=$ $10 \%) \mathrm{KE}=5+10=15 \%$. Variable planned fuel consumption for these conditions at a total run of $102.4 \mathrm{~km}$ is:

$\mathrm{Qn}=0.01 \times 10.5 \times 102.4 \mathrm{~h}(1+0.01 \times 15)=12.37$ liters.

At the average cost of A-92 28.22 UAH / liter in Poltava region (as of 09.03.18), fuel costs are:

$\mathrm{C}_{\text {fuel }}=12.37 \times 28.22=349.08 \mathrm{UAH}$.

According to the company, bus uses gas as a fuel with consumption of $201 / 100 \mathrm{~km}$. Then the costs are as follows:

$\mathrm{Qn}=0.01 \times 20 \times 102.4 \mathrm{~h}(1+0.01 \times 15)=24.58$ liters

At the average cost of, $13.16 \mathrm{UAH} /$ liter (propane butane) and 14.71 UAH / liter (methane) in Poltava region (as of March 9, 2018), the monetary costs are:

(propane-butane) $\mathrm{C}_{\text {fuel }}=24,58 \times 8,16=323.47 \mathrm{UAH}$; (methane) $\mathrm{C}_{\text {fuel }}=24.58 \times 13.29=361.57 \mathrm{UAH}$.
Autogas system is not provided by a manufacturer, but it is mounted by a vehicle owner. The norms of spending resources approved by the Ministry of Infrastructure of Ukraine do not include the costs for converted vehicles, and therefore, taking into account the slight difference in total cost, we use petroleum costs the further calculations.

Expenditure on operating materials includes the cost of materials such as: motor and transmission oils, special oils and plastic lubricants. The need for lubricating materials is calculated for each type of oil or lubricant, based on the consumption of oil per 100 liters of fuel consumption. Cash expenses are calculated on the basis of current actual prices for these materials [19]. The total cost of "Fuel" and "Lubricants" items is:

$\mathrm{C}_{\mathrm{fl}}=349.08+88.56=437.64 \mathrm{UAH}$.

Vehicle maintenance and current repair expenditures include the cost of materials used, spare parts and repairers' wages. These expenditures are determined specifically for $1 \mathrm{~km}$ of run, and for a daily run of $102.4 \mathrm{~km}$ they are as follows:

$\mathrm{C}_{\mathrm{tyr}}=\frac{102,4}{373760}\left[\begin{array}{l}365 \cdot 13,25+74 \cdot 52,73+ \\ +18 \cdot 157,66+\frac{373760 \cdot(292,79)}{1000}\end{array}\right]=32,79 U A H$

Frequency of current repair and maintenance is used in accordance with the normative document [20]. Materials and spare parts consumption is carried out according to the normative document [21]. In calculations of expenses for current repair and maintenance, the value of the standard of expenditure is taken at the level according to models of a similar class. Standard is set in USD and converted into UAH at the average rate of the NBU.

The cost rate in the "Automotive tires" item is determined in accordance with [22] and is:

$\mathrm{C}_{\mathrm{tyr}}=(1206 \times 6 / 60000 \times 1,0) \times 102,4=12.35 \mathrm{UAH}$.

The method of applying the adjustment coefficients is given in [23].

For a private carrier, with a small fleet of vehicles, it is difficult to use "Depreciation deductions" effectively because of inflation of long-term funds accumulation for the purchase of a new unit. Therefore, very often, these funds are spent on other needs of the enterprise, and the replacement of rolling stock is unlikely to occur, which leads to its aging. The way out of this situation is involving of foreign investments (loans, leasing, etc.). In accordance with the classification vehicles are classified in the fifth group with a minimum permissible amortization period of five years. We use a straight-line method of accruing depreciation:

$\mathrm{V}_{\text {dep }}=(448200 \times 10) /(100 \times 365)=122.79 \mathrm{UAH}$.

The "Total Manufacturing Expenditures" item includes the costs of enterprise service, organization of the transport process, enterprise management. In modern conditions, when an enterprise is closely linked to small businesses through vehicles sublease, these expenditures are collected every day by issuing permission to go on a route (technical inspection of entrepreneur's vehicle by company's mechanic and driver's examination by a medical professional before going on the route). Often, these fees differ on different routes (according to attractiveness of passenger traffic flow) and do not depend on the services provided, which leads to misunderstanding between the transporting company and entrepreneurs. On the other hand, these fees should not exceed the statutory provisions laid down in the calculations.

For preliminary calculations of the transportation cost value it is allowed to take total production expenditures at the level of 15$20 \%$ of the total amount of costs for the transportation of the estimated cost which are: 
$V_{\text {TOT.EXP }}=1098,42 * 0,15=164,76 \mathrm{UAH}$.

Estimated cost of work on the route includes all the above listed expenditures and is $1385.97 \mathrm{UAH} /$ day.

The transportation expenditures reflect the expenditures concerning to volume of passengers transported. Transportation expenditure for one passenger is:

week day $-\mathrm{C}_{\mathrm{pas}}=\mathbf{1 3 8 5 . 9 7 / 1 9 3}=\mathrm{UAH} 7.18$ / pass.;

week end $-\mathrm{C}_{\mathrm{pas}}=\mathbf{1 3 8 5 . 9 7 / 1 3 8}=\mathrm{UAH} 10.04 /$ pass.

\section{Conclusion}

Daily operational expenditures on the "Center - Prykhod'ko street" route and the passenger traffic flow volume indicate that the cost for transporting of one passenger per week day is UAH 7.18 / pass, and at week end it is UAH 10.04 / pass. At a socialprivileged (specified) by the city council fare of 3 UAH, carrier's expenditures will be restored provided that at least 21 passengers per run and even distribution of passenger traffic flow are performed. At present, the size of the passenger traffic flow is insufficient, which can be explained by its scattering due to the existence of alternative and overlapped routes. The carrier can cover expenses by fare increase or targeted subsidies (subventions)

Finding the ways to reduce travel time costs can improve the quality of passenger transportation. Being used as a generalization criterion, transportation services allow a compromise between the interests of the carrier and the passenger. The optimal value of the vehicle number on the route is directly proportional to the expenditures of transportation time and is inversely proportional to the operating costs of a public transport enterprise. Also, an increase in the route length, which determines the turnaround time, requires an increase in the optimal number of vehicles.

\section{References}

[1] Passazhyrskye avtomobyl'nye perevozky / VA Hudkov, LB Myrotyn, AV Vel'mozhyn, SA Shyryaev. - M .: Haryacha liniya - Telekom, 2006. - 448 p.

[2] Panchenko SV, Butko TV, Prokhorchenko AV, Parkhomenko LO Formation of an automated traffic capacity calculation system of rail networks for freight flows of mining and smelting enterprises / Naukovyi Visnyk Natsionalnoho Hirnychoho Universytetu.- Issue 2, 2016, P. 93-99.

[3] Shramenko, NY, 2017. The methodological aspect of the study feasibility of intermodal technology of cargo delivery in international traffic. Scientific Bulletin of National Mining University, Vol. 4 (160), pp. 145-150.

[4] Khorovych B Priorytet hromads'koho transportu: krashchi rishennya [Elektronnyy resurs] / B Khorovych // Omnibus. - 2005. №3-4. Rezhym dostupu do na .:http://www.omnibus.ru/arhiv/3-4_2005/uitp/

[5] A Bulletin of Public Transport Statistics: Great Britain 2002 Edition SB. Transport Statistics Bulletin. Department for Transport November. (02) 25.2002.

[6] Delmon J Private Sector Investment in Infrastructure: Project Finance, PPP Projects and Risk. The World Bank and Kluwer Law International. 2009. P. 7.

[7] Moroz, OV and Moroz, MM, 2014. Specific features of city public transport financing (Kremenchuk case study). Actual Problems of Economics, 160(1), pp. 239-246.

[8] Moroz, MM, 2015. Defining the term and the volume of investments on reduction to necessary structure of rolling stock of passenger public transport (Kremenchuk city case study) // Actual Problems of Economics, Vol. 166 (4), p. 235-243.

[9] Ékonomyka avtomobyl'noho transporta: Ucheb. posobye dlya stud. Vyshsh. Ucheb. Zavedenyy / AH Budrin, YV Budryna, MH Hryhoryan i dr .; Pid redaktsiyeyu HA Kononovoy. - M .: Yzdatel'skyy tsentr «Akademyya», 2005.- 320 p.

[10] Napkhonenko NV, Karaeva MR Optimization of the passenger transportation system taking into account dynamically changing passenger flows // SRSTU (NPI) Messenger. SocialEconomicSciencesSeries. - 2013. - No. 4. - P. 109-112
[11] Rossolov A, Zadorozhna V, Kopytkov D, Kush Y, 2017. Research of effectiveness of unimodal and multimodal transportation involving land modes of transport // Eastern-European Journal of Enterprise Technologies.- Vol. 5. - P. 60-69.

[12] Trunina IM, Sushchenko OA, 2016. Creation of innovation clusters as a line of enterprise competitiveness improvement in the field of foreign economic activity // Actual Problems of Economics, Vol. 177 (3), p. 191-198.

[13] Redzyuk AM, Shtanov VF, Ihnatenko OS ta inshi. Zbirnyk zakonodavchykh ta normatyvnykh dokumentiv, shcho rehlamentuyut' diyal'nist' pidpryyemstv avtomobil'noho transportu vsikh form vlasnosti; vypusk 2 - K .: Yumana, 1998. - 528 p.

[14] Metodychni rekomendatsiyi shchodo formuvannya sobivartosti perevezen' (robit, posluh) na transporti, zatverdzheni nakazom Ministerstva transportu Ukrayiny vid 05.02.2001 r. № 65.

[15] Metodychni rekomendatsiyi shchodo vyznachennya rivnya taryfiv na posluhy pasazhyrs'koho avtomobil'noho transportu zahal'noho korystuvannya, zatverdzheni nakazom Ministerstva transportu ta zv'yazku Ukrayiny vid 17.11.2009 № 1175 .

[16] Haluzeva uhoda mizh derzhavnym ahent·stvom avtomobil'nykh dorih Ukrayiny ta profspilkoyu pratsivnykiv avtomobil'noho transportu ta shlyakhovoho hospodarstva Ukrayiny na 2017-2019 roky / [Elektronnyy resurs]. - Rezhym dostupu- // http://ukravtodor.gov.ua/4489/normatyvnopravova_baza/haluzeva

uhoda_mizh_derzhavnym_ahentstvom_avtomobilnykh_dorih_ukrai ny_i_profspilkoiu_hospodarstva_ukrainy_na_2017-2019_roky.html

[17] ZU vid 08.07.10 № 2464 "Pro zbir ta oblik yedynoyi vnesky na zahal'noobov'yazkove derzhavne sotsial'ne strakhuvannya".

[18] Nakaz Ministerstva vydatkiv i zboriv Ukrayiny vid 09.09.2013 r. № 454 "Pro zatverdzhennya Poryadku formuvannya ta podannya strakhuval'nykamy zvitu pro sumy narakhovanoyi yedynoyi vnesky na zahal'noobov'yazkove derzhavne sotsial'ne strakhuvannya".

[19] Normy vytraty palyva ta mastyl'nykh materialiv na avtomobil'nomu transporti, zatverdzheni Ministerstvom transportu Ukrayiny vid 10.02.1998 № 43.

[20] Polozhennya pro tekhnichne obsluhovuvannya ta remont dorodzhen' transportnykh zasobiv avtomobil'noho transportu, zatverdzhenykh nakazom Ministerstva transportu vid 30.03.98r. № 102.

[21] Normy vytrat na tekhnichne obsluhovuvannya ta potochne remont za osnovnymy markamy avtomobiliv, zatverdzheni nakazom Mintransu vid 15.12 .95 r. № 7 / 1-4-1071p.

[22] Normy ekspluatatsiynoho probihu avtomobil'nykh shyn, zatverdzheni nakazom Ministerstva transportu Ukrayiny № 488 vid 15.06.2006r.

[23] Ekspluatatsiyni normy seredn'oho resursu pnevmatychnykh shyn kolesnykh transportnykh zasobiv ta spetsial'nykh mashyn, vykonanykh na kolisnykh shasi, zatverdzhenykh nakazom Ministerstva transportu ta zv'yazku Ukrayiny vid 20.05.2006 № 488 . 